\title{
OPINIÃO
}

\section{Pré-sal e gastança pública ${ }^{\dagger}$}

Yoshiaki Nakano*

Segundo as manchetes da imprensa, o Secretário do Tesouro Nacional comemorou que a operação de capitalização da Petrobras resultará, em setembro, na entrada de caixa de $\mathrm{R} \$ 30$ bilhões, gerando o “maior superávit da história”. O presidente Lula festejou também a capitalização da Petrobras, como "a maior do mundo", que gerou a entrada de uma enxurrada de capitais do exterior aumentando mais de $1.100 \%$, de setembro em relação a agosto, batendo recorde histórico. Os especuladores do mercado financeiro comemoram, na mesma proporção, a apreciação do real, que chegou a R \$1,70 por dólar. Engordando seus polpudos ganhos acima da taxa de juros praticada no Brasil, que permanece a mais alta do mundo, quando o Federal Reserve (Fed, o banco central dos Estados Unidos) pratica taxa próxima a zero.

Essa enxurrada de entrada de capitais e a política de juros do Banco Central estão alimentando a expectativa de novas apreciações do real, que poderá se converter num processo de "profecia que se autorrealiza", porém desestabilizadora e catastrófica, no médio prazo. Veja o ritmo assustador de crescimento no déficit de transações correntes, que deverá superar US\$ 50 bilhões neste ano. Tudo isto é exatamente o que a hipótese de "doença holandesa" prevê. Mais do que isso, o "boom” no setor de recursos naturais resultará num encolhimento do setor de "tradables" manufaturados, como vem acontecendo, e de forma cada vez mais acelerada no Brasil. Esse efeito destruidor do setor de manufaturados é tão maior quanto mais aberta for a conta de capitais, levando a uma especialização crescente do país em setores exploradores de recursos naturais e não "tradables". 1

Para aqueles que se preocupam com o desenvolvimento do país no longo prazo e com as futuras gerações, não há nada a comemorar com a descoberta do pré-sal e capitalização da Petrobras. Ao contrário, os fatos acima apontados confirmam que o Brasil não tem nem instituições, nem maturidade econômica para se beneficiar, a longo prazo, da descoberta de grandes jazidas de petróleo, a exemplo de muitos outros países, como a Venezuela e México, para mencionar apenas os nossos parentes próximos. Não somos a Noruega, que institucionalizou os

\footnotetext{
${ }^{\dagger}$ Artigo publicado no jornal Valor Econômico em 1 de outubro de 2010.

* Ex-secretário da Fazenda do Governo Mário Covas (SP). Professor e Diretor da Escola de Economia de São Paulo da Fundação Getulio Vargas - FGV/EESP.

1 Ver pesquisa cobrindo 90 países e 81 setores manufatureiros. Kareem Ismail, The Structural Manifestation of the "Dutch Disease": The Case of Oil Exporting Countries", IMF Working Paper, abril de 2010.
} 
recursos efetivos vindos da exploração de petróleo, constituindo reserva para o futuro, ou seja, poupança para gerações futuras.

No caso brasileiro, estamos fazendo pior do que faz a Venezuela hoje ou outros países, que apreciam a taxa de câmbio consumindo a receita efetiva de exportação de petróleo. O Brasil está apreciando a taxa de câmbio antecipadamente e consumindo uma receita de exportações, que poderá ou não, se materializar no futuro, provavelmente, muito depois da Olimpíada de 2014, ampliando o passivo externo e a gastança pública. É importante lembrar que a receita futura é ainda incerta e existem riscos e desafios tecnológicos não triviais para extrair petróleo em águas do pré-sal.

De janeiro a agosto deste ano, os gastos do Governo Federal e Banco Central aumentaram 17,2\%, em relação ao mesmo período do ano anterior. A rigor, o Tesouro Nacional está colocando, antecipadamente em caixa, R $\$ 30$ bilhões, próximo de 1\% do PIB, para pagar os aumentos galopantes de consumo do Governo, particularmente aumento de salários do funcionalismo, dado desde 2008. Lembro que somente esses aumentos representam muito mais do que as receitas futuras agora antecipadas. Não estamos consumindo uma receita efetiva de exportações de petróleo, só isto seria desastroso para um país que poupa e investe apenas 19\% do PIB. Estamos antecipando receita futura para pagar gastança passada!

Com a apreciação da taxa de câmbio, além de consumir uma receita futura incerta, estamos destruindo o setor manufatureiro brasileiro que foi construído por gerações passadas, no último século, com a entrada de importações, particularmente de países que mantêm a sua taxa de câmbio ultradepreciada, como a China. Fábricas são fechadas para se transformarem em importadoras. Muitos setores industriais, num processo regressivo, são obrigados a se especializar em atividades exploradoras de recursos naturais. Veja o exemplo do setor de soja, cujas fábricas de óleo foram fechadas, tornando o Brasil exportador de grãos. Da mesma forma, o setor siderúrgico, que vinha alcançando notável renovação e avanços tecnológicos depois da privatização, está se tornando, cada vez mais, exportador de minério de ferro, e o Brasil de exportador, de repente, está importando em torno de 30\% do aço consumido.

Quando analisamos para que setores da indústria os investimentos estão sendo canalizados, dados do IBGE mostram um quadro típico da "doença holandesa": aumentaram, de 1996 a 2008, nos setores baseados em recursos naturais e de petróleo, e diminuíram nos setores de maior valor agregado e intensivos em tecnologia. Não é a toa que o saldo comercial desses últimos setores, que em 2005 era de cerca de US\$ 5 bilhões, tenha se transformado num déficit, que deverá atingir US\$ 60 bilhões. 